Óbudai Egyetem, Élettani Szabályozások Kutatóközpont, ${ }^{1}$ Heim Pál Gyermekkórház, Budapest, ${ }^{2}$ Péterfy Sándor Utcai Rendelőintézet, Budapest, ${ }^{3}$ Miskolci Egyetem Egészségügyi Kar, Elméleti Egészségtudományi Intézet, Miskolc, ${ }^{4}$ Safarik Egyetem Gyermekgyógyászati Klinika, Kassa, Szlovákia ${ }^{5}$

\title{
Mesterséges hasnyálmirigy - A cukorbetegség automatikus kezelése mérnöki megközelítéssel
}

\author{
Kovács Levente dr., ${ }^{(1)}$ Eigner György dr., ${ }^{(1)}$ Czakó Bence, ${ }^{(1)}$ Siket Máté, ${ }^{(1)}$ \\ Almássy Zsuzsana dr., ${ }^{(2)}$ Kocsis Győző dr., ${ }^{(3)}$ Barkai László dr. ${ }^{(4,5)}$
}

\begin{abstract}
Öszefoglalás
A közlemény rövid naprakész áttekintést ad a mesterséges hasnyálmirigy (artificial pancreas: AP) felépitésével és müködésével kapcsolatban, amelynek segitségével automatizált módon lehet a cukorbetegségben szenvedö betegeket kezelni. Ez az interdiszciplináris megközelités ötvözi az orvosi tudományokat, a mérnöki irányitáselméletet, valamint az egészségügyi mérnöki területeket. A folyamatos glukózmonitorozás, valamint az inzulinpumpák megjelenésének segitségével az AP hatékony megoldást nyújthat a jövöben több millió diabeteses beteg kezelése során. Ezen felül a félautomata AP képes garantálni a páciens megfelelö vércukorszintjét. A jelen dolgozatban bemutatjuk az AP általános müködését, valamint ismertetünk néhány praktikus modellezési, valamint szabályozási megoldást is.

Kulcsszavak: mesterséges hasnyálmirigy, diabetes mellitus
\end{abstract}

\section{Artificial pancreas - an engineering approach of diabetes treatment}

Summary: The paper gives a short review on the artificial pancreas (AP), which can be used for automated treatment of diabetic patients. This highly interdisciplinary concept involves beyond medical sciences, control engineering and biomedical engineering knowledge. Having already developed continuous glucose sensor devices and highly performant insulin pumps, the AP can be an efficient solution for millions of people living with diabetes for accurate metabolic conditions management. Furthermore, as a semi-automatic device, AP can guarantee tight blood glucose control. In this paper, we summarize not just the AP concept, but give a short review on the modeling and control solutions as well.

Keywords: artificial pancreas, diabetes mellitus

Rövidítések

AP: mesterséges hasnyálmirigy (artificial pancreas); GOx: glukóz-oxidáz (glucose oxidase); PID: arányos-integrálóderiváló (proportional-integral-derivative) algoritmus; MPC: modellalapú prediktív szabályozás; LPV: lineáris változó paraméterű; LMI: lineáris mátrix egyenlőtlenség; MM: minimálmodell

$\mathrm{N}$ apjainkban a szubkután inzulinadagolás két leggyakrabban alkalmazott módja:

- inzulinbevitel pen-típusú adagolók használatával, ami évtizedek óta bevett eljárás a klinikai gyakorlatban;
- inzulinadagolás inzulinpumpa segítségével, ami egy összetett elektromechanikai készülék és az elmúlt években vált elterjedté.

Mindkét kezelés célja a páciens normoglykaemiás preprandiális $(3,9-6 \mathrm{mmol} / \mathrm{l})$ és postprandialis (pp) vércukorszintjének biztosítása $(<7,8 \mathrm{mmol} / \mathrm{l})$, 
valamint a hypoglykaemiás állapot kialakulásának elkerülése. A terápia tervezésének fontos feltétele, hogy az adagolás során figyelembe kell venni a páciens fiziológiai állapotát - pl. életkorát, testtömegét, egyéb élettani paramétereit -, valamint fizikai aktivitásának mértékét. A terápia során a páciens aktívan jár el, önálló döntéseket hoz és saját életviteléhez, táplálékbeviteléhez igazítja a terápiás tervben foglaltakat.

Az inzulinpumpák, valamint a szöveti glukózszintet folyamatosan mérő szenzorok segítségével lehetőség nyílt a cukorbetegségben szenvedő betegek automatizált kezelésére. E koncepció az ún. „closed loop” rendszer, vagy más néven mesterséges pancreas (AP), ami jelenleg a legkorszerűbb ismert orvostechnikai/mérnöki megoldás a diabetes kezelésére, ${ }^{1,2}$ A mesterséges hasnyálmirigy három fő komponensből tevődik össze: $:^{1,3}$

- inzulinpumpa, amely tárolja és injektálja az inzulint;

- folyamatos glukózmonitorozó rendszer (CGMS), amely képes megbecsülni a vércukorszint megváltozását;

- azon hardver- és szoftverelemek, amelyek biztosítják a szabályozási algoritmus működését és a felhasználói interakciót az eszközzel.

Az AP megvalósítása két különböző módon történhet. Az első lehetőség egy „minden egyben” készülék létrehozása, amely integrálja a mechanikus, elektronikus, valamint szoftveres komponenseket egy készülékben. ${ }^{4}$ A másik elképzelés a megosztott

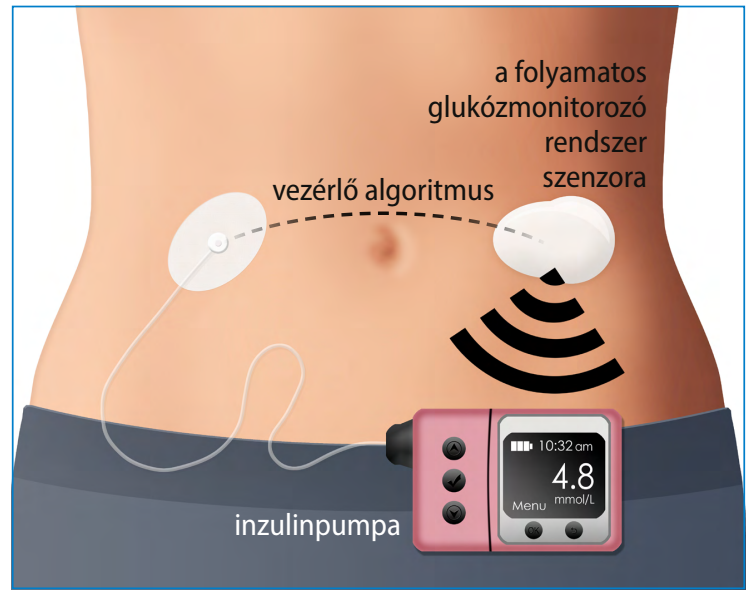

1. ábra. Az AP általános felépitése $e^{15}$ készülék használata, ahol a fontosabb alrendszerek, például az irányítási algoritmus vagy a jelfeldolgozó egység egy külön hardveren fut. ${ }^{5}$

A következőkben az AP koncepció alapvető összetevőinek segítségével kerülnek bemutatásra azok a főbb elemek, amelyek elengedhetetlenek a teljes rendszer működéséhez (1. ábra).

\section{A napjainkban alkalmazott inzulinpumpák}

Az inzulinpumpa tartalmaz egy inzulintartályt, egy grafikus csatlakozási felületet (interfészt), akkumulátort, valamint az inzulin injektálására szolgáló mechanikus és hardveres komponenseket. Napjainkban számos cég kínál működőképes termékeket, amelyekkel automatizáltan adagolható az inzulin a beteg számára. ${ }^{6,7}$

A hagyományos, injekciós gyakorlattal szemben az inzulinpumpát választók száma az utóbbi időben folyamatosan növekszik. Számukat jelenleg több mint egymillióra becsülik világszerte. ${ }^{8}$ Az inzulinpumpák két főbb kategóriába sorolhatók: a katéteres és patch változatba. A hagyományos, katéteres pumpák közé tartoznak az Animas, a Medtronic és a Roche eszközei, amelyek a bőr alá helyezett fém- vagy műanyag kanült kötik össze a pumpa inzulintartályával. Ezzel ellentétben az Omnipod patch rendszerének nincs szüksége vezetékre, az inzulintartály a befecskendezési pont felett van rögzítve.

Mindkét esetben javasolt három-hatnaponta cserélni a kanült. Egy nemrégiben elvégzett átfogó vizsgálat eredménye nem mutatott ki szignifikáns különbséget az egyes gyártók és típusok közötti $\mathrm{HbA}_{1 \mathrm{c}}$-értékek tekintetében. ${ }^{9}$ A kétezres években inkább a hagyományos katéteres pumpák terjedtek el, számos technológiai újításnak köszönhetően azonban napjainkban egyre nő a patch típusú pumpák népszerüsége. ${ }^{10}$

A teljesen automatizált rendszer irányába azok a megoldások mutatnak, ahol az AP három fő komponensét egyre jobban integrálják. Ilyen fontos mérföldkő volt a CGMS rendszer és inzulinpumpa együttes használata, ami lehetővé tette, hogy egy algoritmus hypoglykaemia esetén leállítsa a bazális inzulinadagolást. Ennek egy továbbfejlesztett funkciója már a vércukoresés bekövetkezése előtt képes megszakítani az inzulinbevitelt (ez a Medtronic esetén a $640 \mathrm{G}$ szériától érhető el). ${ }^{11}$ Újítás, 
hogy a Medtronic legújabb MiniMed 670G rendszere képes részben autonóm módon működni a bazális inzulin folyamatos állításával, amit a későbbiekben részletesebben említett „proportionalintegral-derivative" (arányos-integráló-deriváló, röviden PID) szabályozási algoritmus segítségével tud megvalósítani. ${ }^{12}$

A CGMS rendszerek hétnapos üzemidejével szemben az inzulinpumpák kanüljeit három-hatnaponta cserélni kell. Ennélfogva különösen fontos olyan kanülök fejlesztése, amelyekkel növelhető az élettartam és kevesebb cserére van szükség. A jelenleg használt rozsdamentes acél és teflonkanül között nem mutattak ki szignifikáns különbséget a gyulladásos folyamatokat és az élettartamot tekintve. Fontos vizsgálni, hogy a teflon többletköltsége jár-e szignifikáns élettartam-növekedéssel. ${ }^{13}$

\section{CGMS rendszerek használata}

A CGMS rendszerek használata egyre elterjedtebb, tekintettel arra, hogy költségvonzatuk jelentősen alacsonyabb, mint a klasszikus ujjbegyes méréseké. ${ }^{14}$ Előnyük a klasszikus méréssel szemben, hogy a páciens vércukorszintjéről folyamatos visszajelzést adnak, ami a folytonos információ miatt jelentős segítség a terápia beállításához. Ezen felül segítséget nyújt a pácienseknek, hogy szorosabb glikémiás kontroll segítségével elérjék mind a kitűzött glikémiás célokat, mind a kívánt $\mathrm{HbA}_{1 \mathrm{c}}$-szintet. A CGMS használata az inzulinpumpa használatától függetlenül is hasznos minden cukorbeteg páciens számára. Számos olyan klinikai vizsgálatot végeztek 2018-ban is, amelyek bizonyították, hogy különböző korosztályok és betegségtípus esetén segítséget jelent egy ilyen rendszer használata. ${ }^{15} \mathrm{~A}$ mérés gyakoriságának növelésével a páciens a saját kezelését is jobban beállíthatja, továbbá egyéb, a páciens számára fontos statisztikai információk nyerhetők ki.

A CGMS rendszerek alapvetően három fő egységből tevődnek össze: szenzorból, jeladóból és vevőből. Technológiától függően a szenzor és a jeladó egy készülékben is helyet kaphat, nem szükséges különálló egységet képezniük. A CGMS rendszerek megvalósítására eltérő mérési elveken alapuló megoldások léteznek. Az esetek többségében a szerkezet a páciens hasi tájékán van rögzítve, ahol egy vékony katéteren keresztül csatlakozik a bőr szubkután rétegéhez. A leggyakrabban alkalmazott mérési módszer a glukóz-oxidáz (GOx) enzimen alapszik, ami által a beteg vércukorszintje becsülhető a szenzor elektromos tulajdonságainak változása révén. Az enzim a glukóz glükonsavvá alakulását katalizálja, a reakcióban közvetetten elektromos töltés jön létre. Az elektródban létrejövő töltés nagyságából, megfelelő analóg és digitális jelfeldolgozással számolható a becsült glukózkoncentráció.

A CGMS-ek számtalan előnyük mellett hátrányokkal is rendelkeznek. Ezen hátrányok egyrészt a szenzorhasználók edukációjának hiányosságából fakad, mivel esetlegesen nem az előírtaknak megfelelően használják az eszközt. Másrészt mérnöki tervezés szempontjából jelentenek kihívást. A szenzoros mérések adatai a technológiai korlátok miatt átlagosan ötpercenként állnak rendelkezésre, vagyis ötperces mintavételi idővel lehet számolni az automatizált algoritmusok esetén, ami nagyban megnehezíti egy folytonos szabályozó tervezését. ${ }^{16,17}$

Az AP keretein belül használt szabályozási algoritmusok megkövetelik, hogy a mérési adatok megfelelő időközönként rendelkezésre álljanak, ami elsősorban CGMS rendszer használatával lehetséges jelenleg. A szabályozási algoritmusok a beérkező CGMS-adatokat kiértékelik adott módszertan szerint, ami alapján megállapítják az adagolni kívánt inzulin mennyiségét. Gyakorlatilag ez azt jelenti, hogy ha eltérés van a mért vércukorszint és az előírt vércukorszint között, akkor hibajel képződik, és az aktuálisan adagolandó inzulin mennyisége a hibajel mértékével összefüggésben kerül kiszámításra. Mivel az inzulinpumpák gyors hatású inzulinanalógokat használnak (a Magyarországon elérhető hatóanyagok közül aspart, lispro vagy glulisin inzulint), a szabályozási algoritmusok esetében elvárás, hogy ezeknek a készítményeknek a reakciódinamikáját és reakciókinetikáját figyelembe vegyék - ami általában a modellalkotás és alkalmazás területe. A CGMS szempontjából viszont ez azt jelenti, hogy kellően gyorsan kell megbízható adatoknak rendelkezésre állniuk ahhoz, hogy a hibajelképzést és a beadandó mennyiséget az adott algoritmus ki tudja számítani. A napi gyakorlatban az ötperces vércukorszintmérési adat rendelkezésre állása megfelelő a „kvázi-folytonos” és a diszkrét (mintavételezett) algoritmusok tervezéséhez.

Az AP koncepcióval összefüggésben több CGMS rendszert is vizsgáltak klinikai körülmények között az elmúlt években, amelyek kivétel nélkül a GOx enzimtechnológiákra épültek. A tavalyi évben végzett klinikai vizsgálatok döntő többségében három gyártó készülékét alkalmazták, a Medtronic Enlite 
szenzorát, a Dexcom G szériáját (főként G4, G5 és G6) és az Abbott Freestyle Navigator II rendszerét.

Jelenleg a Dexcom G6 az egyik legfejlettebb elérhető CGMS rendszer a piacon, amelynek magyarországi bemutatója 2020-ban várható. A szenzor legnagyobb újításai az AP koncepció szempontjából a tíznapos hordási idő, az újfajta adathozzáférési lehetőségek, okostelefonos megjelenítés, valamint a gyári beállítások használata. Utóbbi lehetővé teszi, hogy a páciensek a szenzor felhelyezését követően ujjbegyes kalibráció nélkül is használhassák a szenzort, amely referenciaérték nélkül is képes megfelelő minőségű méréseket végezni. ${ }^{18}$

A Dexcom G széria egyik legelterjedtebben használt változata a G4, amelyet számos AP-vel összefüggő klinikai felmérésben is sikerrel alkalmaztak (pl. éjszakai vércukorszint-szabályozás, valamint különböző zavaró tényezők, stressz, fizikai aktivitás kapcsán). ${ }^{19,20}$ Érdemes megemlíteni, hogy az elmúlt években megjelentek a beültethető CGMS-szenzorok is, amelyek közül nemrégiben a Senseonics Eversense szenzora kapott FDAengedélyt. Ez 90 napos időtartamra ültethető be. ${ }^{21}$

\section{Az in silico modellezés és a vércukor- szabályozás föbb szempontjai}

Mérnökök, fizikusok és matematikusok régóta törekszenek arra, hogy a körülöttünk lévő világ folyamatait leírják. Egy ilyen valós folyamat, eszköz egyszerűsített reprezentációját modellnek nevezzük. A modellalkotás eszköztárát a matematika, elsősorban differenciálegyenletek szolgáltatják. Ennek az egyszerüsített modellnek a létrehozása nem könnyű feladat. Kellően bonyolultnak kell lennie, hogy az általunk vizsgált folyamatot pontosan leírja, és elég egyszerűnek, hogy a leíró egyenletrendszer matematikailag kezelhető legyen. Élettani folyamatoknál ez külön kihívás, mert sok szerteágazó tulajdonságú, egymással kölcsönhatásban lévő kisebb

$$
\begin{aligned}
\dot{G}(t) & =-\left(p_{1}+X(t)\right) G(t)+p_{1} G_{B}+p(t) \\
\dot{X}(t) & =-p_{2} X(t)+p_{3}\left[I(t)-I_{B}\right] \\
\dot{I}(t) & =\gamma(G(t)-h) t-n\left[I(t)-I_{B}\right]+u(t)
\end{aligned}
$$

\section{2. ábra. A minimálmodell egyenletei ${ }^{1}$}

alrendszer rendkívül komplex hálózataként működik. A szabályozó rendszer tervezéséhez szükséges azonban egy megfelelően pontos matematikai modell, amely képes leírni a glukóz-inzulin interakció fiziológiai működését. Ebben a részben a főbb modellezési megfontolások kerülnek ismertetésre.

A modellezés során érdemes különbséget tenni a pácienstípusok között. Különbséget lehet tenni pl. az intenzív terápiás környezetben történő akut betegellátás és a krónikus/nem sürgősségi betegellátás között, vagy öngondoskodásra képes és képtelen páciens között. Akut beavatkozásra szoruló, öngondoskodásra nem képes fekvőbeteg kerülhet pl. az ellátása során intenzív osztályra, ahol képzett orvosok, egzakt protokollok alapján kontroll alatt tartják az eseményeket. Ebben az esetben érdemesebb tehát egyszerű modelleket alkalmazni, hiszen a folyamatok nagy részét az orvosok kézben tartják. Egy másik megközelítés a krónikus/nem sürgősségi betegellátás (pl. diabetesgondozás) során előforduló kezelési sajátosságokat veszi figyelembe. Ilyenkor a beteg önálló döntéseket hoz, nagymértékű autonómiával rendelkezik saját kezelését, életmódját illetően. Ebből kifolyólag a szabályozó algoritmusnak számos bizonytalansággal vagy ismeretlen helyzettel kell megküzdenie, amelyek befolyásolják a vércukorszintet. A gyakorlatban ez a probléma úgy hidalható át, hogy az egyszerü glukóz-inzulin-dinamikát leíró központi páciensmodell mellett az AP olyan kiegészítő elemeket is tartalmaz, amelyek bizonyos fiziológiai (emésztési, felszívódási modellek) vagy fizikai (eszközök, szenzorok modelljei) folyamatokat írnak le.

Az első diabetesmodellek főleg az egyéni páciensmodellekre fókuszáltak. Ez azt jelenti, hogy mind a struktúra, mind a paraméterek a konkrét páciens élettani tulajdonságaihoz voltak igazítva. A legfontosabb modell ezen a téren az 1980-as évek környékén kifejlesztett minimálmodell (MM) volt. ${ }^{22} \mathrm{Az}$ elmúlt évek során az MM modellt számos új alegységgel kiegészítették, ugyanakkor az alapvető elgondolás megmaradt. Az MM differenciálegyenleteit a 2. ábra szemlélteti.

A modell két fő részből tevődik össze: az első egyenlet írja le a glukózszint változását a vérben, a második az inzulin vércukorszintre gyakorolt hatását, míg a harmadik egyenlet az inzulin kinetikáját. A rendszerben két különböző bemenetet lehet megkülönböztetni. Az első a táplálkozásból fakadó szénhidrát, 
amelyet a p(t) (mg/min) változó jelöl. A másik bemenet maga a külsőleg adagolt inzulin, amelyet ebben a modellben injekciós adagolás formájában feltételezünk és $u(t)$-vel jelöljük (mU/min). Miután a táplálékból felszívódott glukóz bekerül a véráramba, megnő a vércukorszint, amit a $\mathrm{G}(\mathrm{t})(\mathrm{mg} / \mathrm{dl})$ változó jelöl. Ha G(t) értéke eltér a hasnyálmirigy glikémiás céljától, h-tól (mg/dl), akkor a béta-sejtek inzulint injektálnak a véráramba. Ugyanakkor 1-es típusú cukorbetegség (T1DM) esetén (ekkor a gamma [ $\gamma]$ ) paraméter nullával egyenlő, vagyis a teljes tag hatása nulla lesz az egyenletben). A béta-sejtek nem képesek ellátni ezt a feladatot, ami miatt az egyetlen inzulinforrást $\mathrm{u}(\mathrm{t})$ bemenet jelenti. A kapcsolatot a glukóz és az inzulin-dinamika között a glukóz kiürülési rátája, X(t) (1/min) határozza meg, aminek az értéke növekszik, ha az inzulinszint nő. Érdekes megfigyelni az egyenletekben szereplő GB és IB tagokat, amelyek az orvosi terminológiában éhomi vércukorés inzulinszintnek felelnek meg, míg mérnöki szemléletmódban ezek a magára hagyott rendszer állandósult állapotbeli értékei, tehát táplálék és külső inzulinbevitel nélkül idővel a rendszer ezen értékekhez konvergál.

A sürgősségi ellátás során alkalmazott modellek is megtartják az MM struktúráját, viszont ezekben az esetekben az állapotváltozók száma jóval kisebb. Egy rendszer állapotváltozóinak azon mennyiségeket nevezzük, amelyek valamilyen dinamikus (tehát időben változó) tulajdonsággal rendelkeznek és a rendszerünket egyértelműen leírják. Az egyértelmủ leírás mérnöki szempontból azt jelenti, hogy az általunk elvárt pontossággal képes a modell a rendszert reprezentálni. Az állapotváltozók száma jó közelítéssel megadja egy modell komplexitását. A bemutatott minimálmodell három állapotváltozójával - G(t), X(t), I(t) -, ahogy a neve is sejteti, az egyszerűek közé tartozik. Mivel a biológiai folyamatok rendkívül komplexek, nagymértékű egyszerűsítéseket és közelítéseket kell alkalmazni, hogy azok matematikailag kezelhetők maradjanak. Emiatt a modellek megválasztásánál mindig fontos megtalálni a megfelelő egyensúlyt a komplexitás és pontosság vonatkozásában. Például az említett egyszerűbb sürgősségi ellátásnál használt modellek nagyobb hangsúlyt fektetnek a fontosabb kinematikai (pl. eltolási sebesség, diffúzió) és fiziológiai (pl. a máj glukóztermelése) tulajdonságokra. Ezen modellekre fontos példa az új-zélandi ún. Canterbury-modellek osztálya, ugyanakkor egyéb formalizmusok is ismertek. ${ }^{3,23}$

A fekvőbeteg-modellekkel szemben a járóbetegmodellek több részletet is figyelembe vesznek. Példának okáért precízebben leírják a szövetek inzulinfüggő, valamint az idegrendszer inzulinfüggetlen glukózfelvételét, a máj folytonos glukózkibocsátását (a glukoneogenezis és a glikogénlebontás során), az inzulin és glukóz abszorpcióját, diffúzióját és kiürülését, esetleg egyéb releváns folyamatokat. A legtöbb ilyen modell T1DM esetében jól használható, a modell szempontjából az egyetlen különbséget az inzulintermelés hiánya okozza.

A széles körben alkalmazott fekvőbeteg-modell gyakorlati példája pl. az olasz-amerikai Padova-Virginia kutatócsoport által kifejlesztett modellcsalád, amely alapján az FDA által egyedüliként jóváhagyott szimulátor is készült. ${ }^{24,25}$ Ezen felül más öszszetett modellekkel is találkozhatunk, mint például az angol Cambridge vagy az amerikai MIT egyetemen kifejlesztett modellek, amelyek akár több mint húsz állapotváltozót tartalmaznak. ${ }^{26,27}$ Érdemes megemlíteni, hogy bár ezek a modellek rendkívül komplexek, kizárólag T1DM leírására képesek.

A T1DM esetében alkalmazott modellek adaptálhatóak 2-es típusú diabeteses (T2DM-es) betegek leírására is, adott feltételek figyelembevételével. A T2DM megbetegedés modellezése öszszetettebb feladat, ugyanis figyelembe kell venni a reziduális inzulintermelést, aminek a leírása matematikailag rendkívül bonyolult. Ezen felül gyakorlati gondot jelent, hogy nehéz megállapítani a beteg konkrét diabeteses állapotát. Az inzulintermelés ugyanis a betegség kezdeti szakaszában - kompenzatorikusan - igen magas, ami hosszú időn keresztül fennállhat. Egy idő után azonban a béta-sejtek a folyamatos terhelés miatt kimerülnek, és az endogén inzulintermelés csökkenni kezd. Ilyenkor a T2DM elkezd átfordulni egy T1DM-szerű állapotba. Ezen felül számos környezeti hatás is befolyásolhatja az inzulin termelését, amelyeknek a nagy részét nem lehet modellezni, így csak „külső zavarásként” lehet matematikailag reprezentálni. Külön problémát jelent az inzulin eliminációjának modellezése, mivel ez a folyamat általában szakaszosan, impulzusszerűen történik (tehát nem folytonos), amit a hagyományos modellezési technikákkal nehéz reprezentálni. ${ }^{28}$ Ennek a problémának a kezelésére csak az utóbbi években jelentek meg modellek, amelyekkel a T2DM is leírható matematikailag. Ezentúl kulcsfontosságú volt az ún. kettős diabetes állapot (T1DM során kialakuló inzulinrezisztencia, mint a T2DM fő tulajdonsága) leírása, valamint az inzulinkiválasztás pulzáló viselkedésének a modellezése. ${ }^{29}$ Érdemes megjegyezni, hogy a modell tovább pontosítható a béta-sejtek viselkedésének leírásával is. ${ }^{30}$ 


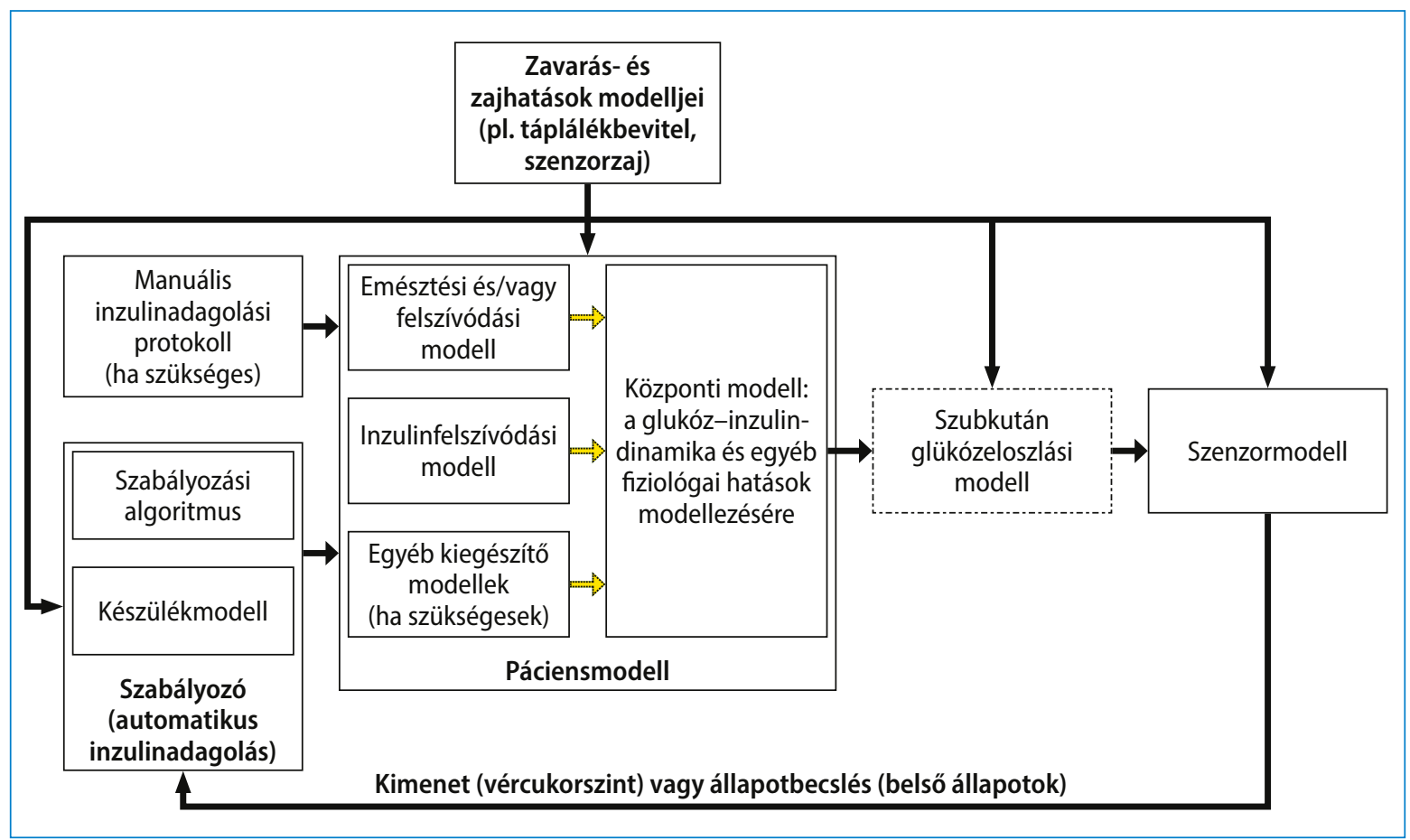

\section{3. ábra. Az AP modellezése során felmerülő föbb koncepciók}

Modellezési szempontból a táplálkozás a vércukorszabályozási rendszer terhelésének, „zavarásnak” tekinthető. A zavaró hatások leküzdésére és a páciensek vércukorszintjének szabályozására automatikus inzulinadagoló szabályozókat lehet kidolgozni. Emellett a terápiás célok elérése érdekében konvencionális inzulinterápiára is szüksége lehet, amit manuális adagolási protokollal lehet leírni. A páciens matematikai modellezésének szempontjából az ételek és inzulin felszívódási idejét, az inzulin farmakokinetikáját stb. lehet modellezni, így a gyógyszer hatásmechanizmusa a páciensmodellben „életszerübben” jelennek meg. A modellezés középpontjában azonban a glukóz-inzulin-dinamika, vagyis fóként az inzulin farmakodinamikai modellezése áll - vagyis annak matematikai megfogalmazása, hogyan redukálja az inzulin a vér cukorszintjét. A glukózeloszlási modell leírja, hogy a vércukor a szubkután szövetekben hogyan jelenik meg (milyen eloszlással, milyen koncentrációval) - amiböl a szenzormodell „mintavételezi" a szubkután réteg cukorszintjét és amelyből a modell megbecsüli a vércukorszint aktuális értékét. A szabályozási algoritmus a szenzorok (ez esetben a szenzormodell) jelét használja fel a visszacsatoláshoz, vagyis a vércukorszint becslését a szabályozó részére, így realizálva a "closed-loop" (zárt szabályozási) rendszert.

A fentebb említett általános modellezési feladatok mellett a páciensmodell esszenciális részét képezhetik az emésztési, valamint felszívódási modellek, mivel ezek a fiziológiai folyamatok direkt módon hatnak a vércukorszintre. Az emésztési modellekről általában elmondható, hogy lényegesen több állapotváltozót tartalmaznak, mivel a táplálkozás teljes folyamatát (az étel elfogyasztásától kezdve a glukóz felvételéig) le kell fedniük. Ezzel szemben a felszívódási modellek egyszerűbbek, mivel „csak” a glukóz útját kell reprezentálniuk a gasztrointesztinális rendszerből a véráramba. Ezek a modellek általában egyedül a szénhidrátbevitelre fókuszálnak, ugyanakkor léteznek részletesebb leírások is. ${ }^{31}$ Ellentétes megközelítést alkalmaznak például az olasz De Gaetano, valamint Dalla Man által bevezetett modellek, amelyek szintén csak a szénhidrátbevitelre koncentrálnak, viszont egyszerűbben beilleszthetők az AP keretébe, valamint megfelelően precízek az általuk szolgáltatott eredmények. ${ }^{32,33}$

A szubkután glukózdinamika modellezése is számos fontos kérdést vet fel, ugyanis a piacon kapható folyamatos glukózmonitorozó rendszerek az interstitialis tér glukózszintjét mérik, ami alapján egy algoritmus segítségével becsülik meg a legvalószínűbb vércukorszintet. ${ }^{17} \mathrm{~A}$ diffúziómodell általában 
a páciens élettani folyamatait leíró modellbe van beágyazva, de számos példa van arra is, hogy maga a szenzormodell tartalmazza ezt a leírást. ${ }^{25,26,34}$

Érdemes megemlíteni, hogy az AP ezen részét egyszerű kompartment modellekkel is sikeresen lehet modellezni. A kompartmentmodellek a kompartmentekkel írják le a test bizonyos egységeit, például folyadéktereit, izmokat, amelyekben általában koncentráció típusú mértékegységekkel reprezentálhatók a modellezés szempontjából fontos anyagok. A kompartmentek közötti kölcsönhatásokat, dinamikát farmakodinamikai és farmakokinetikai megfontolások alapján állítják fel. A modellezési típus egyszerűsége adja a legnagyobb előnyét is, kisszámú kompartment használatával is „életszerü” modelleket lehet létrehozni. ${ }^{35}$

Az esetek túlnyomó részében a különféle zajokat és zavarásokat a már említett modellek explicit tartalmazzák. A páciens-, valamint szenzormodellekben a zajokat véletlenszerű (sztochasztikus) jelekkel, például ún. fehér zajjal reprezentálják, míg az enzimalapú szenzor öregedése egy kiszámítható (determinisztikus) zavarásként jelenik meg a rendszerben. Az AP során felmerülő modellezési problémákat a 3. ábra szemlélteti.

Egy utolsó fontos pont a modellezés során maga a tesztelési folyamat, amellyel összefüggésben szükséges kihangsúlyozni az étkezési protokollok fontosságát. A kész rendszer valós tesztelését szimulációs vizsgálatok előzik meg, amelyeknek fontos eleme a véletlenszerű táplálékbevitel számítógépes vizsgálata. Ez a gyakorlatban azt jelenti, hogy a szimuláció közben változhat a táplálékbevitel hossza, mennyisége, valamint az összetétele minden egyes teszt során, amivel csökkenthetők a valós tesztek során fellépő kockázatok. Összefoglalva, a glukózhomeosztázist leíró modellt virtuális páciensnek nevezzük, amely páciensnek a viselkedését számítógépes szimulációk segítségével vizsgálhatjuk általunk meghatározott sémák szerint adagolva a szénhidrátot és az inzulint - ez az eljárás az úgynevezett „in silico” tesztelés.

\section{Szabályozási algoritmusok}

Az AP harmadik fontos összetevőjét a szabályozási algoritmus jelenti, amely az automatizált módszertan „lelke”. Az élettani folyamatokat leíró matematikai modellek és hatékony szabályozási algoritmusok nélkül nem lehetne meghatározni a megfelelő inzulinmennyiséget.

Mivel az inzulinpumpákat az orvosi gyakorlatban a T1DM-es betegek kezelésére használják, ezért a szabályozási algoritmusok többsége is ennek a kezelésnek az automatizálására lett kifejlesztve. A fő elvárás az AP-val szemben, hogy a zavaró hatások ellenére (bevitt táplálék, testmozgás stb.) lehetőleg a páciens vércukorszintjét a normoglykaemiás $(3,6-6 \mathrm{mmol} / \mathrm{l})$ tartományban tartsa úgy, hogy a beteg részéről csak minimális beavatkozás legyen szükséges. Továbbá fő kritérium, hogy az AP használatával automatizált módon elkerülhető legyen a veszélyesen alacsony vércukorszint, amely a páciens életét veszélyeztetheti.

Mivel a cukorbetegség intenzíven kutatott területe az egészségügyi mérnöki tudományterületnek (ún. biomedical engineering), ezért az irodalomban számos szabályozási módszer AP-hoz való adaptációjára találhatunk példát.

A legígéretesebb irányok közé tartozik a modellalapú prediktív szabályozás (MPC), a lágy számítási (pl. fuzzy) szabályrendszeren alapuló, valamint a klasszikus PID és robusztus szabályozási megoldások használata. ${ }^{36}$

Minden szabályozási algoritmus a következő egyszerű megfontoláson alapszik. Mielőtt beavatkoznánk bármilyen folyamatba, először ismernünk kell a szabályozandó értéket adott pillanatban, amit mérésnek nevezünk. Az AP esetében a mért jellemző maga a beteg vércukorszintje, amelynek az értékét a CGMS rendszer szolgáltatja a mért szöveti glukózérték alapján. A mért érték és az általunk elérni kívánt célérték különbségéből előállíthatunk egy ún. hibajelet. Alapjában véve az egyes algoritmusokat az különbözteti meg, hogy ezt a hibajelet milyen formában veszi figyelembe és esetleg milyen más információt igényel a beavatkozás (inzulinmennyiség) meghatározásához. Az algoritmusoknak meg kell felelniük bizonyos minőségi és mennyiségi elvárásoknak. Minőségi követelmény a vércukorszint megfelelő tartományban való tartása, míg mennyiségi kritériumként az adagolt inzulin mennyiségét lehet példaként felhozni.

Az első AP-szabályozási algoritmusok PID-alapúak voltak, ugyanis egyszerűek, emiatt ipari alkalmazások esetében mind 
a mai napig leggyakrabban ezt alkalmazzák. A korábbiakban említetteknek megfelelően ez az algoritmus úgy működik, hogy minden egyes időpillanatban megvizsgálja a CGMS-ből érkező, valamint a kívánt vércukorszintet, amelyeket összehasonlítva a hiba nagyságával arányos hibajelet képez. Az algoritmus ezen kívül figyelembe veszi az előző hibajelek értékét (az integrálját), valamint a hiba változásának meredekségét (deriváltját) is. Ezek alapján az algoritmus előállítja a megfelelő inzulinbemenetet a három tag súlyozott összegének segítségével. A szabályozó algoritmusról elmondható, hogy egyszerű az implementációja, viszont érzékeny mindenféle előre nem programozott körülményre. Bár a PID alapkoncepciója nem túl bonyolult, mégis bíztató eredményeket értek el robusztus PID szabályozókkal vagy kapcsoló (switching) PID szabályozókkal az AP-környezetben. ${ }^{37,38}$

Az MPC ma az AP legfejlettebb és legelterjedtebb szabályozási technikája, ugyanakkor ez a módszer igen érzékeny mind a páciens belső tulajdonságainak változására (pl. öregedési folyamatok következtében más modellparaméterek írják le jól a pácienst), mind a páciensek közötti eltérésekre és a külső zavarokra. Az MPC egy modellalapú megközelítés (vagyis pontos matematikai modellt feltételez, innen ered az előbb említett hátránya), amely predikciót alkalmaz, vagyis megbecsüli a jövőbeni vércukorszintet a rendelkezésre álló információk és az aktuálisan adagolt inzulinmennyiség alapján. Ez azt jelenti, hogy a szabályozó egy matematikai modell (például a minimálmodell), adott költségfüggvény, valamint egyéb információk alapján meghatározza azt az inzulinmennyiséget, amit adagolni szükséges ahhoz, hogy a szabályozási célok idővel teljesüljenek. A költségfüggvény írja le a tulajdonképpeni szabályozási célokat, mint például a felhasznált inzulin mennyisége, a vércukorszint variabilitása stb. ${ }^{39}$

Lágy számítási módszerekkel is lehet találkozni a szakirodalomban az AP-val kapcsolatban, viszont ezeknek a módszereknek a klinikai vizsgálata csak az elmúlt néhány évben vált időszerűvé. ${ }^{29} \mathrm{~A}$ mostanában divatos gépi tanuló algoritmusok (machine learning) alkalmazására is vannak kísérletek, azonban ezek használata még erősen kísérleti stádiumban van. ${ }^{40}$

Az elmúlt években modern robusztus szabályozások is feltűntek az AP-koncepció keretein belül. Ezen szabályozások célja, hogy kiküszöböljék a determinisztikus zavarokat, amelyek a fiziológiai eltérésekből fakadnak, valamint a táplálékbevitelt mint vércukorszintet terhelő zavarhatást. Más szavakkal, a modern robusztus szabályozások célja, hogy általános biztonsági garanciákat adjanak az AP működése során. Ebből fakadóan az adott robusztus szabályozás képes lehet mind a paramétervariabilitásokból, a táplálékbevitelből és esetlegesen más effektusokból adódó zavaró hatásokat minimalizálni. Egy érdekes példa a lineáris változó paraméterű (LPV) módszertan alkalmazása, ami bizonyíthatóan képes elérni a szabályozási célt fennálló zavarok esetén is. ${ }^{41,42,43}$ Egy másik ígéretes lehetőség az LPV kombinálása a lineáris mátrix egyenlőtlenség (LMI) alapú módszerekkel. ${ }^{44}$ A legújabb irány ezen módszertan keretein belül a tenzorszorzat (TP) transzformáción alapuló LMI szabályozó tervezés, azonban ez a módszer még nem lett validálva a gyakorlatban. ${ }^{45}$ Utóbbi módszertanok lehetővé teszik a már említett paramétervariabilitások és kedvezőtlen matematikai tulajdonságok egységes kezelését és jelentősen egyszerűsítik a szabályozótervezést komplex esetben, valamint kedvező tulajdonságokkal bírnak a zavaró hatások minimalizálása érdekében.

A fent leírt megközelítéseken kívül léteznek még kettős (duális) hormonalapú szabályozók is, amelyek nemcsak inzulint, hanem glükagont is adagolhatnak. A kettős hormonszabályozók nagy előnye a hagyományos AP-koncepcióval szemben, hogy képesek hatékonyabban kezelni a külső zavarokat, mint például a nagyobb mennyiségü, előre nem jelzett élelmiszerbevitelt, valamint a nagy intenzitású testmozgást. Ez a konceptuálisan eltérő új megközelítés kezd teret nyerni a AP-kutatók körében, valamint a klinikai vizsgálatok is bíztató eredményekkel szolgáltak. Mindazonáltal vannak kutatások, amelyek nem mutattak ki szignifikáns eltérést a hagyományos módszerrel szemben bizonyos korcsoportokban, és azt is figyelembe kell venni, hogy a kettős hormonkezelés miatt a módszer gyakorlati alkalmazása is bonyolultabb. ${ }^{46,47}$

A szabályozási algoritmusok fontos aspektusa a gyakorlati tesztelésük, validációjuk. Az elmúlt években számos klinikai teszt során bíztató eredményeket szolgáltattak az alkalmazott „,closed-loop” (zárt hurkú) mesterséges hasnyálmirigy megoldások. Kutatók vizsgálták az AP alkalmazhatóságát T2DM esetében is, ahol a páciens kórházi felügyelet alatt tartózkodott, ami alapján 
látható volt, hogy az AP alkalmazása jobb vércukorszinthez vezetett a kezelés alatt, összehasonlítva az ember által meghatározott adagolással. ${ }^{48}$ Más tanulmányok vizsgálták a „closed-loop” szabályozások hatékonyságát testmozgás esetében is, amely magában foglalja az előre nem jelzett emelkedett, valamint a hosszú távú megerőltető fizikai aktivitást is. ${ }^{49}$ Ezen kívül vizsgálták még az előre nem jelzett, nagy mennyiségű táplálékbevitel is, amire pl. a Zone-MPC algoritmust alkalmazták, amely sztochasztikus elvek mentén képes volt jobb vércukorszint-szabályozást elérni más módszerekkel szemben. ${ }^{50}$

\section{Összegzés}

Bár a cukorbetegség a mai napig lényegében gyógyíthatatlan betegség, az évek során kifejlesztett gyógymódok automatizálásával az AP vonzó lehetőség számos páciens számára, mivel a használata kényelmesebb, mint a konvencionális módszereké. Munkánkban rövid, a klinikai diabetológiát művelő szakemberek számára is lényegesnek gondolt áttekintést kívántunk adni az AP-vel kapcsolatos technikákról, eszközökről, valamint a felmerülő szabályozási problémákról. Az elmúlt években széles körű klinikai vizsgálatok eredményeként már megvásárolhatók a piacon biztonságos AP-eszközök, ugyanakkor még számos fejlesztés szükséges ahhoz, hogy az AP egy széles körűen alkalmazott és teljesen automatizált módszerré váljon a cukorbetegségben szenvedő emberek számára.

Közlésre érkezett: 2019. május 10.

Közlésre elfogadva: 2019. október 8.

\author{
A levelezésért felelős szerző: \\ Dr. Eigner György \\ Óbudai Egyetem, Élettani Szabályozások \\ Kutatóközpont \\ 1034 Budapest, Bécsi út 96/B \\ E-mail: eigner.gyorgy@nik.uni-obuda.hu
}

Irodalom

1. Chee F, Fernando T: Closed-loop control of blood glucose. Berlin Heidelberg: Springer-Verlag, 2007.

2. Boughton CK, Hovorka R: Advances in artificial pancreas systems. Science Translational Medicine 2019; 11(484): eaaw4949. doi:10.1126/scitranslmed.aaw4949

3. Kovatchev B: The artificial pancreas in 2017: The year of transition from research to clinical practice. Nat Rev Endocrinol 2018; 14(2): 74-76. doi:10.1038/nrendo.2017.170

4. Medtronic MiniMed $670 \mathrm{G}$ System, User Guide, 2018.

5. Tandem Diabetes Care t:slim X2 Insulin Pump - Dexcom G5 Mobile CGM Enabled, User Guide, 2018.

6. Sherr J, Tamborlane WV: Past, present, and future of insulin pump therapy: Better shot at diabetes control. Mt Sinai J Med 2008; 75(4): 352-361. doi: $10.1002 / \mathrm{msj} .20055$

7. VallaV: Therapeutics of diabetes mellitus: Focus on insulin analogues and insulin pumps. Exp Diabetes Res 2010; 2010: 178372. doi:10.1155/2010/178372

8. Nimri R, Dassau E, Segall T, Muller, I, Bratina N, Kordonouri O, et al.: Adjusting insulin doses in patients with type 1 diabetes who use insulin pump and continuous glucose monitoring: Variations among countries and physicians. Diabetes Obes Metab 2018; 20(10): 2458-2466. doi:10.1111/dom.13408

9. Leelarathna L, Roberts SA, Hindle A, Markakis K, Alam T, Chapman A, et al: Comparison of different insulin pump makes under routine care conditions in adults with Type 1 diabetes. Diabet Med 2017; 34(10): 1372-1379. doi: $10.1111 /$ dme. 13412

10. Karges B, Schwandt A, Heidtmann B, Kordonouri O, Binder E, Schierloch U, et al: Association of insulin pump therapy vs. insulin injection therapy with severe hypoglycemia, ketoacidosis, and glycemic control among children, adolescents, and young adults with type 1 diabetes. JAMA 2017; 318(14): 1358-1366. doi:10.1001/jama.2017.13994

11. Abraham MB, Nicholas JA, Smith GJ, Fairchild JM, King BR, Ambler GR, et al.: Reduction in hypoglycemia with the predictive low-glucose management system: A long-term randomized controlled trial in adolescents with type 1 diabetes. Diabetes Care 2018; 41(2): 303-310. doi:10.2337/dc17-1604

12. Messer LH, Forlenza GP, Sherr JL, Wadwa RP, Buckingham BA, Weinzimer SA, et al: Optimizing hybrid closed-loop therapy in adolescents and emerging adults using the MiniMed 670G System. Diabetes Care 2018; 41(4): 789-796. doi:10.2337/dc17-1682

13. Hauzenberger JR, Münzker J, Kotzbeck P, Asslaber M, Bubalo V, Joseph JI, et al: Systematic in vivo evaluation of the time-dependent inflammatory response to steel and Teflon insulin infusion catheters. Scientific Reports 2018; 8(1): 1132. doi:10.1038/s41598-017-18790-0

14. Murphy HR, Feig DS, Sanchez IJ, de Portu S, Sale A, CONCEPTT Collaborative Group: Modelling potential cost savings from use of real-time continuous glucose monitoring in pregnant women with Type 1 diabetes. Diabet Med June 2019. doi:10.1111/dme. 14046

15. Heinemann L, Fleming GA, Petrie JR, Holl RW, Bergenstal RM, Peters AL: Insulin pump risks and benefits: A clinical appraisal of pump safety standards, adverse event reporting, and research needs: A joint statement of the European Association for the Study of Diabetes and the American Diabetes Association Diabetes Technology Working Group. Diabetes Care 2015; 38(4): 716-722. doi:10.2337/dc15-0168

16. Klonoff DC, Ahn D, Drincic A: Continuous glucose monitoring: A review of the technology and clinical use. Diabetes Res Clin Pract 2017; 133: 178-192. doi:10.1016/j.diabres.2017.08.005

17. Eigner Gy, Kovács L: Realization methods of continuous glucose monitoring systems. Buletinul stiintific al universitatii politehnica din timisoara romania seria automatica si calculatorae 2014; 59(73): 175-182. 
18. Dexcom G6, continuous glucose monitoring system, User guide, 2018. https: 1/s3-us-west-2.amazonaws.com/dexcompdf/G6-CGM-Users-Guide.pdf

19. Bequette BW, Cameron F, Buckingham BA, Maahs DM, Lum J: Overnight hypoglycemia and hyperglycemia mitigation for individuals with type 1 diabetes: How risks can be reduced. IEEE Control Systems 2018; 38(1): 125-134. doi:10.1109/MCS.2017.2767119

20. Turksoy K, Littlejohn E, Cinar A: Multimodule, multivariable artificial pancreas for patients with type 1 diabetes: Regulating glucose concentration under challenging conditions. IEEE Control Systems 2018; 38(1): 105-124. doi:10.1109/MCS.2017.2766326

21. Christiansen MP, Klaff $L$, Brazg R, Carlson G, Tweden KS: A prospective multicenter evaluation of the accuracy of a novel implanted continuous glucose sensor: PRECISE II. Diabetes Technol Ther 2018; 20(3): 197-206. doi:10.1089/dia.2017.0142

22. Bergman RN, Phillips LS, Cobelli C: Physiologic evaluation of factors controlling glucose tolerance in man: Measurement of insulin sensitivity and beta-cell glucose sensitivity from the response to intravenous glucose. I Clin Invest 1981; 68(6): 1456-1467.

23. Wong XW, Chase JG, Shaw GM, Hann CE, Lotz T, Lin J, et al: Model predictive glycaemic regulation in critical illness using insulin and nutrition input: A pilot study. Med Eng Phys 2006; 28(7): 665-681. doi:10.1016/j.medengphy.2005.10.015

24. Dalla Man C, Rizza RA, Cobelli C: Meal simulation model of the glucoseinsulin system. IEEE Trans Biomed Eng 2007; 54(10): 1740-1749. doi:10.1109/TBME.2007.893506

25. Man CD, Micheletto F, Lv D, Breton M, Kovatchev B, Cobelli C: The UVA/ PADOVA type 1 diabetes simulator: new features. J Diabetes Sci Technol 2014; 8(1): 26-34. doi:10.1177/1932296813514502

26. Wilinska ME, Chassin LJ, Acerini CL, Allen JM, Dunger DB, Hovorka $\mathrm{R}$ : Simulation environment to evaluate closed-loop insulin delivery systems in type 1 diabetes. J Diabetes Sci Technol 2010; 4(1): 132-144. doi:10.1177/193229681000400117

27. Sorensen JT: A physiologic model of glucose metabolism in man and its use to design and assess improved insulin therapies for diabetes. 1985. https: // dspace.mit.edu/handle/1721.1/15234. Accessed May 3, 2019.

28. Skjaervold NK, Östling D, Hjelme DR, Spigset 0, Lyng 0, Aadahl P: Blood glucose control using a novel continuous blood glucose monitor and repetitive intravenous insulin boluses: Exploiting natural insulin pulsatility as a principle for a future artificial pancreas. Int J Endocrinol 2013; 2013(245 152): 1-7. doi:10.1155/2013/245152

29. Kong JD, Kumar SS, Palumbo P: DDE Models of the glucose-insulin system A useful tool for the artificial pancreas. In: Delitala M, Ajmone Marsan G, eds. Managing Complexity, Reducing Perplexity. Springer Proceedings in Mathematics \& Statistics. Springer International Publishing; 2014; 109-117.

30. Palumbo P, Ditlevsen S, Bertuzzi A, De Gaetano A: Mathematical modeling of the glucose-insulin system: A review. Math Biosci 2013; 244(2): 69-81. doi:10.1016/j.mbs.2013.05.006

31. Arleth T, Andreassen S, Federici MO, Benedetti MM: A model of the endogenous glucose balance incorporating the characteristics of glucose transporters. Comput Methods Programs Biomed 2000; 62(3): 219-234. doi:10.1016/50169-2607(00)00069-9

32. De Gaetano A, Panunzi S, Matone A, Samson A, Vrbokiva J, Bendlova B, et al: Routine OGTT: A robust model including incretin effect for precise identification of insulin sensitivity and secretion in a single individual. PLoS ONE 2013; 8(8): e 70875 . doi:10.1371/journal.pone.0070875

33. Dalla Man C, Camilleri M, Cobelli C: A system model of oral glucose absorption: Validation on gold standard data. IEEE Trans Biomed Eng 2006; 53(12 Pt 1): 2472-2478. doi:10.1109/TBME.2006.883792
34. Scuffi C, Lucarelli F, Valgimigli F: Minimizing the impact of time lag variability on accuracy evaluation of continuous glucose monitoring systems. J Diabetes Sci Technol 2012; 6(6): 1383-1391. doi:10.1177/193229681200600618

35. Huyett LM, Dassau E, Zisser HC, III FJD: Glucose sensor dynamics and the artificial pancreas: The impact of lag on sensor measurement and controller performance. IEEE Control Systems 2018; 38(1): 30-46. doi:10.1109/MCS.2017.2766322

36. Peyser T, Dassau E, Breton M, Skyler IS: The artificial pancreas: Current status and future prospects in the management of diabetes. Ann N Y Acad Sci 2014; 1311: 102-123. doi:10.1111/nyas. 12431

37. Kamath S: Model based simulation for Type I diabetic patients. Asian Am J Chem 2013; 1: 11-19.

38. Bondia J, Romero-Vivo S, Ricarte B, Diez JL: Insulin estimation and prediction: A review of the estimation and prediction of subcutaneous insulin pharmacokinetics in closed-loop glucose control. IEEE Control Systems 2018; 38(1): 47-66. doi:10.1109/MCS.2017.2766312

39. Pinsker JE, Laguna Sanz AJ, Lee JB, Church MM, Andre C, Lindsey LE, et al.: Evaluation of an artificial pancreas with enhanced model predictive control and a glucose prediction Trust index with unannounced exercise. Diabetes Technol Ther 2018; 20(7): 455-464. doi:10.1089/dia.2018.0031

40. Mhaskar HN, Pereverzyev SV, van der Walt MD: A deep learning approach to diabetic blood glucose prediction. Front Appl Math Stat 2017; 3(14): 1-11. doi:10.3389/fams.2017.00014

41. Kovács L: A robust fixed point transformation-based approach for type 1 diabetes control. Nonlinear Dynamics 2017; 89(4): 2481-2493.

42. Kovács L: Linear parameter varying (LPV) based robust control of type-I diabetes driven for real patient data. Knowledge-Based Systems 2017; 122: 199-213. doi:10.1016/j.knosys.2017.02.008

43. Colmegna P, Sánchez-Peña RS, Gondhalekar R: Linear parameter-varying model to design control laws for an artificial pancreas. Biomed Signal Process Control 2018; 40: 204-213. doi:10.1016/j.bspc.2017.09.021

44. Szalay P, Eigner G, Kovács LA: Linear matrix inequality-based robust controller design for type-1 diabetes model. IFAC Proceedings Volumes 2014; 47(3): 9247-9252. doi:10.3182/20140824-6-ZA-1003.02451

45. Galambos P, Kuti J, Baranyi P: On the Tensor Product based qLPV modeling of bio-inspired dynamic processes. In: 2013 IEEE 17th International Conference on Intelligent Engineering Systems (INES). 2013; 79-84. doi:10.1109/INES.2013.6632787

46. Gingras V, Rabasa-Lhoret R, Messier V, Ladouceur M, Legault L, Haidar A: Efficacy of dual-hormone artificial pancreas to alleviate the carbohydratecounting burden of type 1 diabetes: A randomized crossover trial. Diabetes Metab 2016; 42(1): 47-54. doi:10.1016/j.diabet.2015.05.001

47. Bally L, Thabit H, Hartnell S, Andereggen E, Ruan Y, Wilinska ME, et al: Closed-loop insulin delivery for glycemic control in noncritical care. N Engl J Med 2018; 379(6): 547-556. doi:10.1056/NEJMoa 1805233

48. Thabit H, Hartnell S, Allen JM, Lake A, Wilinska ME, Ruan Y, et al.: Closedloop insulin delivery in inpatients with type 2 diabetes: A randomised, parallel-group trial. Lancet Diabetes Endocrinol 2017; 5(2): 117-124. doi:10.1016/52213-8587(16)30280-7

49. Breton MD, Cherñavvsky DR, Forlenza GP, DeBoer MD, Robic J, Wadwa RP, et al: Closed-loop control during intense prolonged outdoor exercise in adolescents with type 1 diabetes: The artificial pancreas Ski study. Diabetes Care 2017; 40(12): 1644-1650. doi:10.2337/dc17-0883

50. Forlenza GP, Cameron FM, Ly TT, Lam D, Howsmon DP, Baysal N, et al.: Fully closed-loop multiple model probabilistic predictive controller artificial pancreas performance in adolescents and adults in a supervised hotel setting. Diabetes Technol Ther 2018; 20(5):335-343. doi:10.1089/dia.2017.0424 